Article

\title{
First Report of Glyphosate-Resistant Biotype of Eleusine Indica (L.) Gaertn. in Europe
}

\author{
Donato Loddo $^{1, *(\mathbb{D}, \text { Gaetano Imperatore }}{ }^{2}$, Andrea Milani ${ }^{1}{ }^{\circledR}$, Silvia Panozzo ${ }^{1}{ }^{(}$, \\ Silvia Farinati ${ }^{1}$, Maurizio Sattin ${ }^{1}$ (D) and Giuseppe Zanin ${ }^{2}$ \\ 1 Institute for Sustainable Plant Protection (IPSP-CNR), National Research Council of Italy, \\ Viale dell'Università 16, 35020 Legnaro, Italy; andrea.milani@ipsp.cnr.it (A.M.); silvia.panozzo@cnr.it (S.P.); \\ silvia.farinati@ipsp.cnr.it (S.F.); maurizio.sattin@cnr.it (M.S.) \\ 2 Department of Agronomy, Food, Natural Resources, Animals and Environment, DAFNAE, \\ University of Padua, Viale dell’Università 16, 35020 Legnaro, Italy; gaetano.imperatore@unipd.it (G.I.); \\ giuseppe.zanin@unipd.it (G.Z.) \\ * Correspondence: donato.loddo@cnr.it; Tel.: +39-049-827-2822
}

Received: 9 October 2020; Accepted: 28 October 2020; Published: 31 October 2020

check for updates

\begin{abstract}
Glyphosate-resistant biotypes of Eleusine indica (L.) Gaertn. have been detected in Asia, the Americas but not in Europe. The aim of this study was to evaluate resistance levels and possible target site resistance mechanisms of an E. indica biotype (19-1) collected from a plant nursery in Southern Italy where poor glyphosate efficacy was reported. Two dose-response experiments were conducted to evaluate the sensitivity of biotype 19-1 to glyphosate in comparison with two susceptible checks. 5-enolpyruvylshikimate-3-phosphate synthase (EPSPS) sequencing was performed to identify possible mutations conferring the resistance. The susceptible biotypes were completely controlled at the glyphosate recommended field dose of $360 \mathrm{~g}$ ae ha ${ }^{-1}$, while $50 \%$ of the plants of biotype 19-1 survived at $1440 \mathrm{~g}_{\text {ae ha }}{ }^{-1}$. The resistance index of biotype 19-1 ranged between 5.8 and 7.3 for the response variables of fresh weight reduction and plant survival, respectively. All the plants surviving glyphosate application and sampled for DNA analyses had the point mutation P106A. The biotype 19-1 can be confirmed as glyphosate-resistant, representing the first glyphosate-resistant population of E. indica in Europe.
\end{abstract}

Keywords: goosegrass; glyphosate resistance; herbicide resistance; plant nursery

\section{Introduction}

Glyphosate inhibits the enzyme 5-enolpyruvylshikimate-3-phosphate synthase (EPSPS), hindering plant production of aromatic amino acids and thus leading to plant death. Glyphosate is the most used herbicide worldwide, mainly due to the rapid diffusion of genetically modified (GM) glyphosate-tolerant crops across millions of hectares in North and South America and Australia [1,2]. It has been extensively used for decades as the main weed control tool in perennial tree crops, plant nurseries, gardens, parks and other non-agricultural areas. The main reasons for the success of glyphosate are the wide spectrum of weed species controlled, including some troublesome perennials, its limited toxicity and low cost $[1,2]$. However, the widespread, often exclusive, use of glyphosate over a prolonged period and across huge cultivated areas is causing a continuous selection pressure on weed communities, inevitably leading to the evolution of weed biotypes resistant to this herbicide [2]. The first glyphosate-resistant (GR) biotype of Lolium rigidum Gaud. was reported in 1996 in Australia [3] and since then the number of resistant populations has been increasing in different countries. The first glyphosate-resistant (GR hereinafter) biotype was reported in 1996 in Lolium rigidum Gaud. from Australia [3] and since then the number of resistant species (or biotypes) has been increasing in different countries. GR biotypes are 
currently reported for 50 weed species (24 dicots and 26 monocots), across all continents [4]. Globally, most GR biotypes evolved in GM glyphosate-tolerant crops such as maize, soybean, oilseed rape and cotton [5]. In Europe, the cultivation of GM glyphosate-tolerant crops is not allowed, therefore the situation is completely different. Most European GR weed biotypes have evolved in perennial crops, such as orchards, olive groves and vineyards, and belong to the genus Conyza [6-8] and Lolium $[9,10]$. More recently, GR biotypes of Sorghum halepense (L.) Pers. and Hordeum murinum subsp. leporinum (Link) Arcang were found in Spain [11,12].

Eleusine indica (L.) Gaertn., or goosegrass, is an annual diploid grass species $(2 n=18)$. Considered native to Africa and Asia [13], it is currently distributed in warm and temperate areas worldwide and is listed among the most problematic weeds [14]. In Italy E. indica was reported for the first time in 1879 [15] but until the early 1980s it was not very widespread [16]. After that its spread increased, favored by modification of land use and climate change, reaching the current status of "invasive alien of anthropic environments" [17]. E. indica has $\mathrm{C}_{4}$ physiology and it grows fast in full sunlight and warm conditions, while shading by plant canopy strongly limits its growth [18]. E. indica is consequently a major weed in annual row-crops with limited canopy or slow growth, but it can also colonize the edges of annual crops such as maize and rice. In Europe, E. indica is prevalent in nurseries, orchards, ridges, and roadsides due to its tolerance to diverse environmental disturbances such as heat, drought and mowing.

A wide range of herbicides have been used to control E. indica in various crops; however, resistant biotypes to several herbicides with different Sites of Action (SoA) have been reported worldwide since the 1970s [4]. E. indica was the second species to evolve resistance to glyphosate, with the first GR population detected in 1997 in a fruit orchard in Malaysia [19]. Since then, GR populations have been reported in other Asian countries, such as China [20], the Philippines [21], Indonesia [22], but also Brazil [23], Mexico [24] and the USA [25]. E. indica is one of the most important weed species in terms of number of countries and crops where GR populations have been reported [5]. Moreover, E. indica populations with multiple resistance to glyphosate, glufosinate, paraquat and acetyl CoA carboxylase (ACCase) -inhibiting herbicides [26] or glyphosate and cyhalofop-butyl [27] have recently been described. Target site resistance mechanisms, i.e., single and double amino acid substitutions at positions 102 or 106 of the EPSPS are known to confer glyphosate resistance to E. indica. The single amino acid substitution at position 106 is the most common, although it confers a low-to-intermediate resistance level [28-30]. Four different amino acid substitutions at position 106 (proline to serine P106S, proline to threonine P106T, proline to leucine P106L, proline to alanine P106A) have been described $[21,29,31,32]$. P106S is the most frequent substitution in all areas where GR biotypes of E. indica occurred, such as Malaysia [32], the Philippines [21], Mexico [24], the USA [30], and Brazil [33]. A double mutation in EPSPS at positions 102 and 106 (T102I + P106S (TIPS)) was identified in some highly resistant $E$. indica populations [28,34]; however, this double EPSPS mutation has a relevant fitness cost for the species [35]. Gene amplification of EPSPS is another resistance mechanism conferring low resistance level, if present alone $[29,31,36]$. However, highly resistant populations, with both EPSPS amplification and P106S or P106A mutations, have recently been identified in Mexico and China [24,29].

Herbicide resistance has never been reported for E. indica in Europe or the Mediterranean area [4]. However, poor control after repeated glyphosate applications was recently reported in a plant nursery in Southern Italy. Therefore, a study was conducted to confirm the presence of a glyphosate-resistant biotype and investigate the potential involvement of a target site resistance mechanism.

\section{Materials and Methods}

\subsection{Seed Collection and Plant Growing Conditions}

Seeds of the putative GR biotype, named 19-1, of E. indica were collected at a plant nursery in Southern Italy $\left(41^{\circ} 10^{\prime} \mathrm{N}, 14^{\circ} 09^{\prime} \mathrm{E}\right.$, Caserta province) in autumn 2019 from plants surviving repeated 
glyphosate applications. Limited glyphosate efficacy on E. indica had been observed in this farm and the surrounding areas since 2018, but it only became problematic for the farm operations in 2019 . E. indica plants were growing in an area of the farm where pots with ornamental plants were maintained in outdoor conditions and the ground covered with plastic mulch. Plants of E. indica emerged mostly in gaps or holes of the mulch and only seldom in the pots. The limited competition by other weeds, thanks to the presence of plastic mulches, and the absence of shading by crop canopy allowed these E. indica plants to grow rapidly, reach a large size and produce many seeds (Figure 1). Other plants of E. indica emerged along the margins of the gravel roads between the different fields of the plant nursery. Even if environmental conditions were probably less favorable here, those plants were also fully grown and developed.

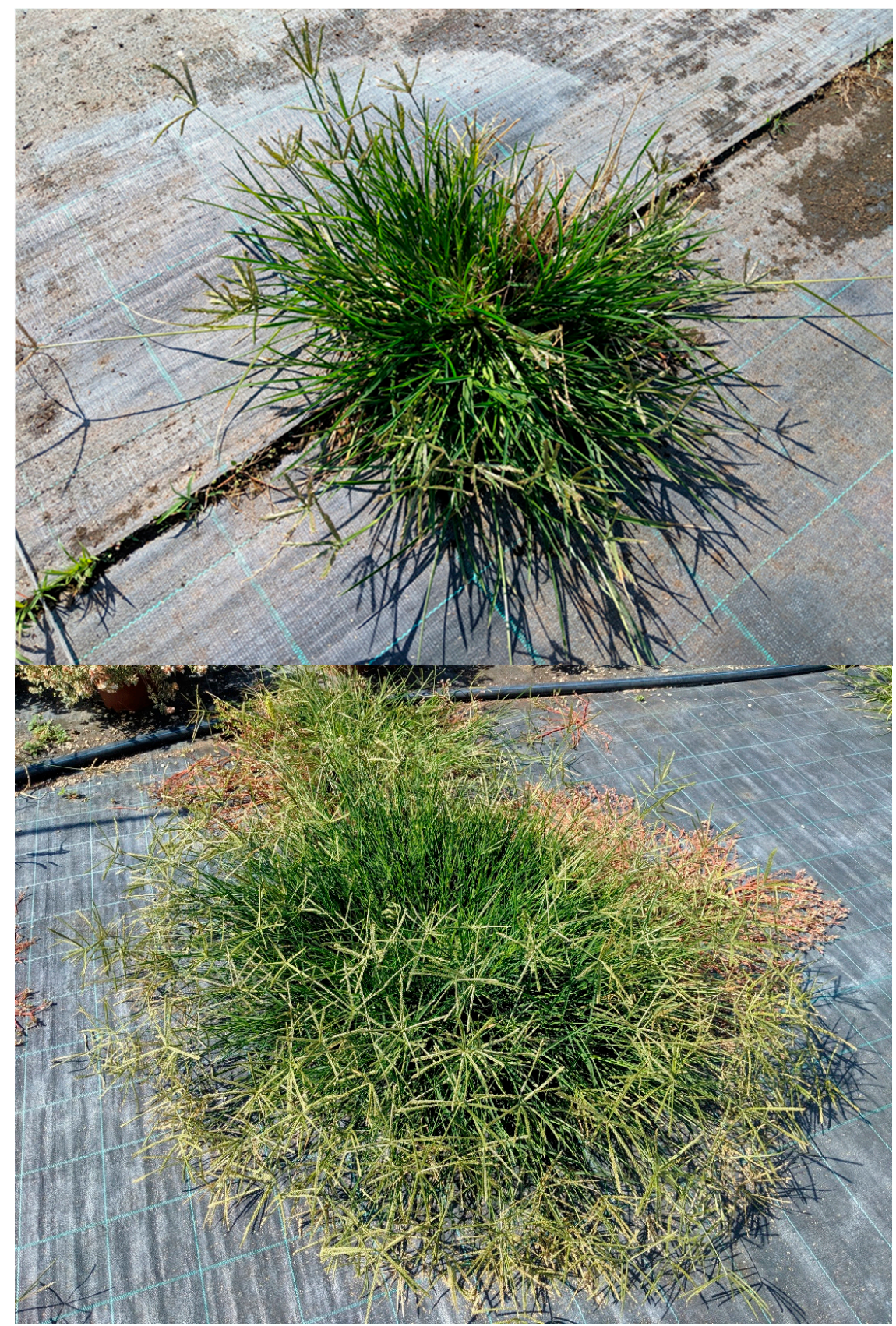

Figure 1. Plants of Eleusine indica (L.) Gaertn. that emerged from holes and gaps of plastic mulches. These plants were survivors to repeated glyphosate applications. 
The standard weed control strategy in cultivated and uncultivated areas of the plant nursery was based on weed patch spraying (3-4 applications per year) with glyphosate (2.6 g ae $\mathrm{L}^{-1}$ of spray solution). Herbicide application was performed using a weeding lance equipped with spray hood for localized weed control. When the farmer noticed in summer 2019 that this E. indica biotype completely survived the herbicide treatments, he decided to perform an additional application (5 applications in total) but without achieving better control. Two additional populations (18-S and 19-S), collected

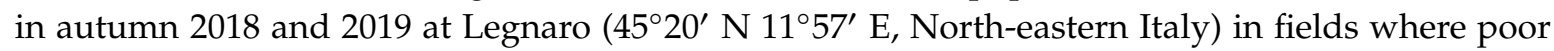
control with glyphosate had never been reported, were included in the experiments as susceptible reference checks.

After collection, seeds of the three biotypes were left to dry at room temperature $\left(20^{\circ} \mathrm{C}\right)$ for 2 weeks and then stored at $4{ }^{\circ} \mathrm{C}$ until the start of the experiment. Seeds were put in petri dishes filled with peat substrate and placed in a germination cabinet at a temperature regime of 28 (light) / 18 (dark) ${ }^{\circ} \mathrm{C}$ and a $12 \mathrm{~h}$ photoperiod. The cabinet was equipped with neon tubes providing a photosynthetic photon flux density (PPFD) of $15-30 \mu \mathrm{mol} \mathrm{m}^{-2} \mathrm{~s}^{-1}$. Seedlings were transplanted at the cotyledon stage into plastic trays (volume $6 \mathrm{~L}$ ) filled with a mixed substrate (silt loam soil $62 \%$, sand $35 \%$, and peat $3 \%)$. Fifteen seedlings were transplanted into each tray. Trays were then placed in a greenhouse where favorable temperature and substrate moisture were maintained throughout the experiments.

\subsection{Dose-Response Experiments}

Two dose-response experiments were conducted to evaluate glyphosate efficacy on the biotypes. Herbicide application (Roundup Power 2.0, Monsanto Agricoltura Italia S.p.A., Via Giovanni Spadolini, 5, 20141 Milano, Italy; glyphosate content $360 \mathrm{~g}_{\text {ae }}{ }^{-1}$ ) was done at the 1-2 tillers or BBCH 21-22 growth stage [37] using a precision bench sprayer with a boom equipped with three flat fan hydraulic nozzles (TeeJet XR11002-VK, Glendale Heights, IL, USA), with a spray volume of $300 \mathrm{~L} \mathrm{ha}^{-1}$ applied at a pressure of $215 \mathrm{kPa}$ and speed of $0.75 \mathrm{~m} \mathrm{~s}^{-1}$. E. indica plants were treated with a range of glyphosate doses $\left(22.5,45,90,180,360,720,1440,2880\right.$ and $5760 \mathrm{~g}$ ae ha ${ }^{-1}$, i.e., from $1 / 16$ to 16 times the recommended label dose of $360 \mathrm{~g}$ ae ha-1). Only the putative GR biotype (19-1) was treated with the two highest doses ( 2880 and $5760 \mathrm{~g}$ ae ha ${ }^{-1}$ ). Untreated controls were also included for all biotypes. The experimental layout was a completely randomized design with three replicates, i.e., three trays of 15 plants each. Plant survival was evaluated 3 weeks after treatment ( 3 WAT) and expressed as percentage of the plants counted before the treatment in each tray. Plants showing no active growth were considered as dead. Fresh weight of the above-ground biomass, including both dead and alive plants, was measured for each replicate and expressed as percentage of the mean value of the untreated replicates of the same biotype.

\subsection{Statistical Analyses}

Means and standard errors were estimated for plant survival and fresh weight of each treatment. Non-linear regression analysis was performed to estimate $\mathrm{ED}_{50}$ and $\mathrm{ED}_{90}$, (i.e., the glyphosate dose required to kill $50 \%$ and $90 \%$ of the treated plants, respectively) and $\mathrm{GR}_{50}$ and $\mathrm{GR}_{90}$ (i.e., the glyphosate dose which causes a growth reduction of $50 \%$ and $90 \%$, respectively in comparison to the untreated plants for each biotype) and their standard errors. This analysis was conducted using the Windows Excel ${ }^{\circledR}$ macro BIOASSAY ${ }^{\circledR}[38]$ and adopting a log-logistic model:

$$
Y=C+\left\{\frac{D-C}{\left[1+\left(\frac{x}{I_{50}\left(O R I_{90}\right)}\right) b\right]}\right\}
$$

where $Y$ is the fresh weight or plant survival, $C$ and $D$ are the lower and upper asymptotes, $I_{50}$ (or $I_{90}$ ) is the dose resulting in a $50 \%$ (or $90 \%$ ) decrease in plant biomass or survival, $b$ is the slope. The upper asymptote of survival data was constrained to 100 for biological reasons and to improve the estimates 
of other parameters, whereas no constraints were imposed considering fresh weight data. Data of each biotype were analyzed as a single curve to estimate its specific parameters and the two experiments were first analyzed separately. An ad hoc lack-of-fit F-test was successively performed for each biotype, by comparing data of the two experiments, to assess whether the data could be pooled. This would allow a single set of parameters to be estimated for each biotype. In order to evaluate the level of glyphosate resistance of the putative GR biotype (19-1), a Resistance Index (RI) was estimated as the ratio between the $\mathrm{ED}_{50}$ (or $\mathrm{GR}_{50}$ ) of biotype 19-1 and the mean $\mathrm{ED}_{50}\left(\right.$ or $\mathrm{GR}_{50}$ ) of the two susceptible reference biotypes (18-S and 19-S):

$$
\mathrm{RI}=\frac{\mathrm{ED}_{50} \text { or } \mathrm{GR}_{50}(19-1)}{\text { Mean } \mathrm{ED}_{50} \text { or } \mathrm{GR}_{50}(18-\mathrm{S}, 19-\mathrm{S})}
$$

\subsection{EPSPS Sequencing}

Genomic DNA (gDNA) was extracted from 10 plants of biotype 19-1 that were alive 3 weeks after being treated with the glyphosate dose of $360 \mathrm{~g}$ ae ha ${ }^{-1}$ and four untreated plants of 19-S biotype. In brief, 2-3 fresh leaves were collected from each plant and frozen at $-18^{\circ} \mathrm{C}$ until DNA extraction; leaves were transferred into a $2 \mathrm{~mL}$ tube (with two disposable iron beads) and ground at room temperature with TissueLyser II (Qiagen, Hilden, Germany), with no buffer. After 1-2 min grinding, a cetrimonium bromide (CTAB) protocol for gDNA extraction was used [39]. The gDNA quantity and quality were determined by gel electrophoresis and analysis with a Nanodrop (Thermo Fisher Scientific, Waltham, MA, USA). Primers were designed to amplify the sites of EPSPS gene known to confer resistance to glyphosate if mutated (positions 102 and 106), using deposited EPSPS E. indica sequences (GenBank accessions JN004269.1 and JN004268.1). Codes and primer sequences $\left(5^{\prime}-3^{\prime}\right)$ were: EI_EPSP_F2, TCTCAGGGAACAACTGTGGTG and EI_EPSP_R2, GGCAGTCAGTGCCAAGGAAA.

Amplifications were performed using GoTaq ${ }^{\circledR}$ G2 Hot Start Polymerase (Promega Corportation, Fitchburg, WI, USA) in a $25 \mu \mathrm{L}$ mixture including $5 \mu \mathrm{L}$ of $5 \times$ Green GoTaq Flexi Buffer, deoxynucleoside triphosphates (dNTPs) mix (0.2 $\mathrm{mM}$ each), $\mathrm{MgCl}_{2}(3 \mathrm{mM})$, forward and reverse primers $(0.4 \mu \mathrm{M})$, $0.125 \mu \mathrm{L}$ GoTaq DNA Polymerase, and $25 \mathrm{ng}$ DNA. The PCR program was as follows: 2 min at $95^{\circ} \mathrm{C}$, 35 cycles of $30 \mathrm{~s}$ at $95^{\circ} \mathrm{C}, 30 \mathrm{~s}$ at $58^{\circ} \mathrm{C}, 35 \mathrm{~s}$ at $72{ }^{\circ} \mathrm{C}, 5 \mathrm{~min}$ at $72{ }^{\circ} \mathrm{C}$. PCR products were purified with NucleoSpin ${ }^{\circledR}$ Gel and PCR Clean-up kit (Macherey-Nagel GmbH \& Co., Düren, Germany) following the manufacturer's instructions. Once purified, amplicons were Sanger-sequenced by BMR Genomics (BMR Genomics S.r.l., Padova, Italy) with EI_EPSP_F2 and analyzed with FichTV (Geospiza Inc., Seattle, WA, USA). All sequences (ab1 files) were deposited in a dedicated repository [40].

\section{Results}

\subsection{Dose-Response Experiment}

Significant differences in the response to glyphosate application were observed in both experiments between the putative GR biotype (19-1) and two susceptible reference biotypes (18-S and 19-S). The susceptible biotypes were completely controlled (survival $0 \%$ ) at $360 \mathrm{~g}$ ae ha $\mathrm{h}^{-1}$, while the putative GR biotype (19-1) showed $100 \%$ and $46 \pm 5.4 \%$ of plant survival at 720 and $1440 \mathrm{~g}$ ae ha ${ }^{-1}$, respectively. Plant survival significantly decreased at the dose of $2880 \mathrm{~g}$ ae ha ${ }^{-1}$, but complete control of biotype 19-1 was achieved only at the dose of $5760 \mathrm{~g}_{\text {ae }} \mathrm{ha}^{-1}$.

Since the lack-of-fit F-test identified no significant differences between repeated experiments, the data were pooled. The two susceptible biotypes (18-S and 19-S) had a very similar response. Biotype 19-1 had a lower response to glyphosate application in terms of both plant survival and fresh weight (Figures 2 and 3). Different values were estimated for the $\mathrm{ED}_{50,90}$ and $\mathrm{GR}_{50,90}$ for the putative resistant and susceptible biotypes (Table 1). $\mathrm{ED}_{50}$ and $\mathrm{ED}_{90}$ values of the susceptible biotypes were lower than 250 and $400 \mathrm{~g}_{\text {ae }} \mathrm{ha}^{-1}$, respectively, while those of biotype 19-1 were estimated at around 1400 and $2000 \mathrm{~g}$ ae ha ${ }^{-1}$, respectively. Similarly, $\mathrm{GR}_{50}$ and $\mathrm{GR}_{90}$ values of the susceptible 
biotypes were lower than 250 and $500 \mathrm{~g}$ ae ha ${ }^{-1}$, respectively, while $\mathrm{GR}_{50}$ and $\mathrm{GR}_{90}$ of biotype 19-1 were approximately 1000 and $2000 \mathrm{~g}$ ae ha ${ }^{-1}$, respectively. The estimated Resistance Indexes (RI) of biotype 19-1, in comparison with the mean of the two susceptible biotypes, were 7.3 and 5.8 when calculated with plant survival or fresh weight reduction, respectively.

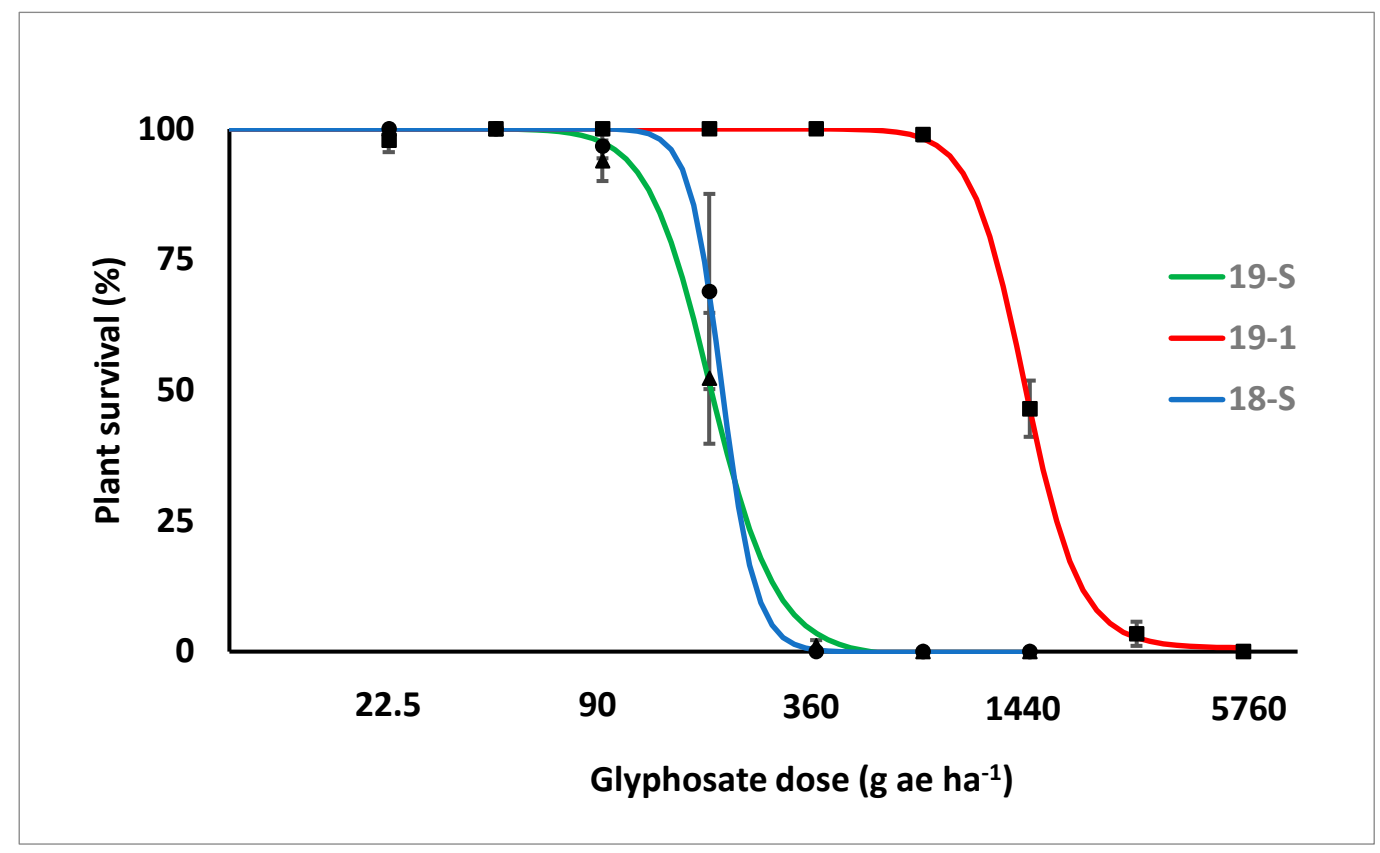

Figure 2. Plant survival response (\%) to increasing glyphosate dose of the putative GR biotype (19-1, red line) and the two susceptible reference biotypes (18-S and 19-S, blue and green lines, respectively). Values are the mean of the two experiments, i.e., six replicates. Bars represent standard errors.

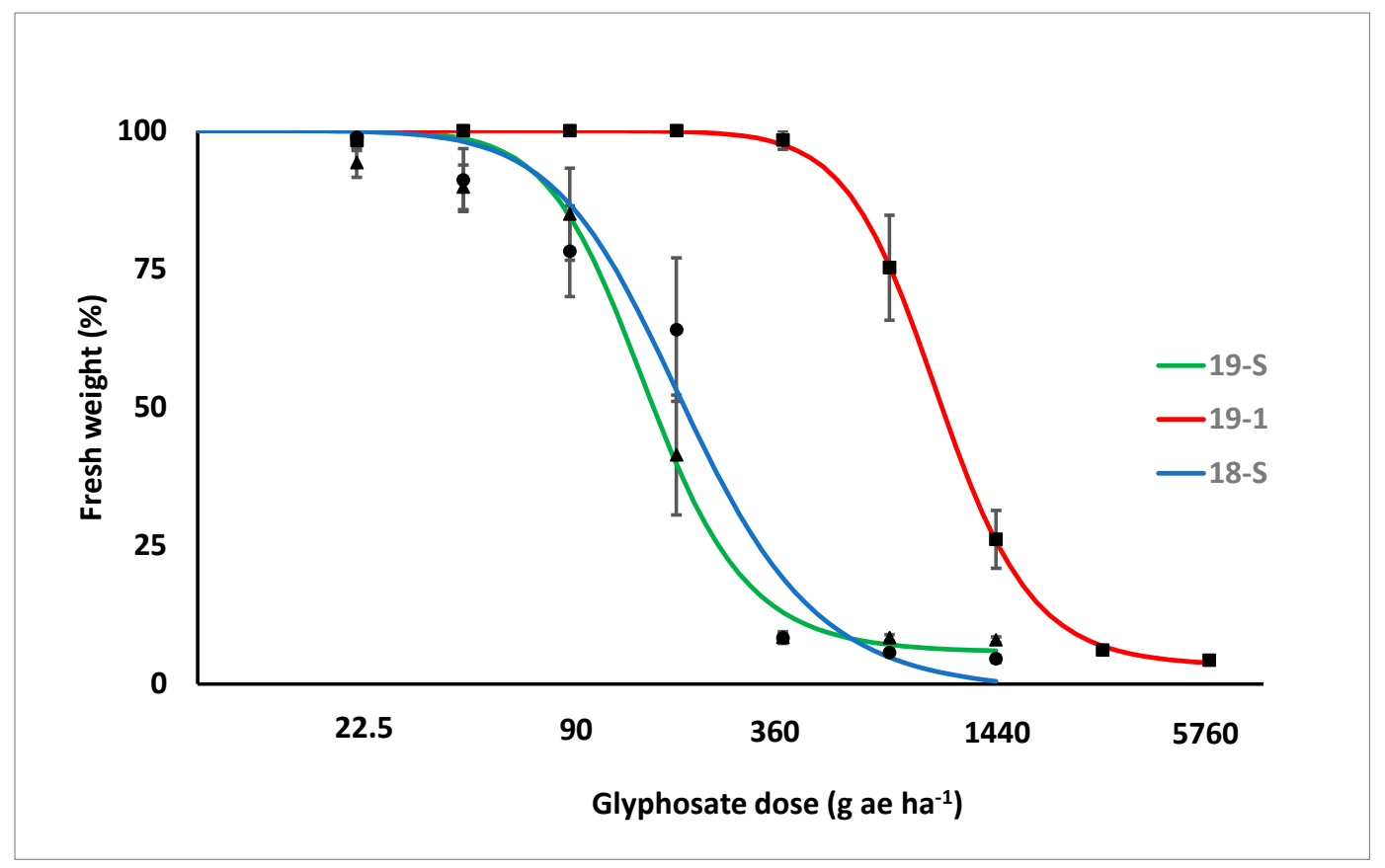

Figure 3. Fresh weight reduction response (expressed as \% of the untreated control) to increasing glyphosate dose of the putative glyphosate-resistant (GR) biotype (19-1, red line) and the two susceptible reference biotypes (18-S and 19-S, blue and green lines, respectively). Values are the mean of the two experiments, i.e., six replicates. Bars represent standard errors. 
Table 1. Values of effective dose of glyphosate for $50 \%$ and $90 \%$ estimated plant death (ED 50 and $\left.\mathrm{ED}_{90}\right)$ and fresh biomass reduction $\left(\mathrm{GR}_{50}\right.$ and $\mathrm{GR}_{90}$ ) for the putative GR biotype (19-1) and the two susceptible reference biotypes (18-S and 19-S), plus Resistance Index (RI) of the putative GR biotype.

\begin{tabular}{|c|c|c|c|}
\hline Biotype & $\mathrm{ED}_{50}$ & $\mathrm{ED}_{90}$ & RI \\
\hline \multicolumn{4}{|c|}{$\mathrm{g}$ ae ha ${ }^{-1}$} \\
\hline $19-1$ & $1402 \pm 20.9$ & $2030 \pm 172.1$ & 7.3 \\
\hline $18-\mathrm{S}$ & $199 \pm 30.7$ & $264 \pm 146.1$ & \\
\hline \multirow[t]{3}{*}{$19-5$} & $183 \pm 7.6$ & $295 \pm 44.9$ & \\
\hline & $\mathrm{GR}_{50}$ & $\mathrm{GR}_{90}$ & RI \\
\hline & \multicolumn{2}{|c|}{$\mathrm{g} \mathrm{ae} \mathrm{ha}^{-1}$} & \\
\hline $19-1$ & $999 \pm 49.5$ & $1931 \pm 206.4$ & 5.8 \\
\hline $18-\mathrm{S}$ & $192 \pm 20.5$ & $480 \pm 124.0$ & \\
\hline $19-5$ & $50 \pm 12.0$ & $311 \pm 56.0$ & \\
\hline
\end{tabular}

Mean values plus standard errors. Resistance Index (RI) was estimated as the ratio between the $\mathrm{ED}_{50}$ (or $\mathrm{GR}_{50}$ ) of the 19-1 and the mean $\mathrm{ED}_{50}$ (or $\mathrm{GR}_{50}$ ) of the two susceptible reference biotypes (18-S and 19-S).

\subsection{EPSPS Sequencing}

All plants had the wild type codon ACT (threonine) at position 102, while all the (10) plants of biotype 19-1 sampled among the survivors from glyphosate dose of $360 \mathrm{~g}$ ae ha ${ }^{-1}$ had the point mutation CCA to GCA at position 106 of the EPSPS gene (Figure 4), which caused an amino acid change from proline to alanine (P106A). The presence of a single peak in the electropherograms indicated that all plants were homozygous for this mutation. No other polymorphisms were observed along the sequence obtained with that primer combination. No mutations of the EPSPS gene were detected in any plants (four) of the susceptible biotype 19-S.
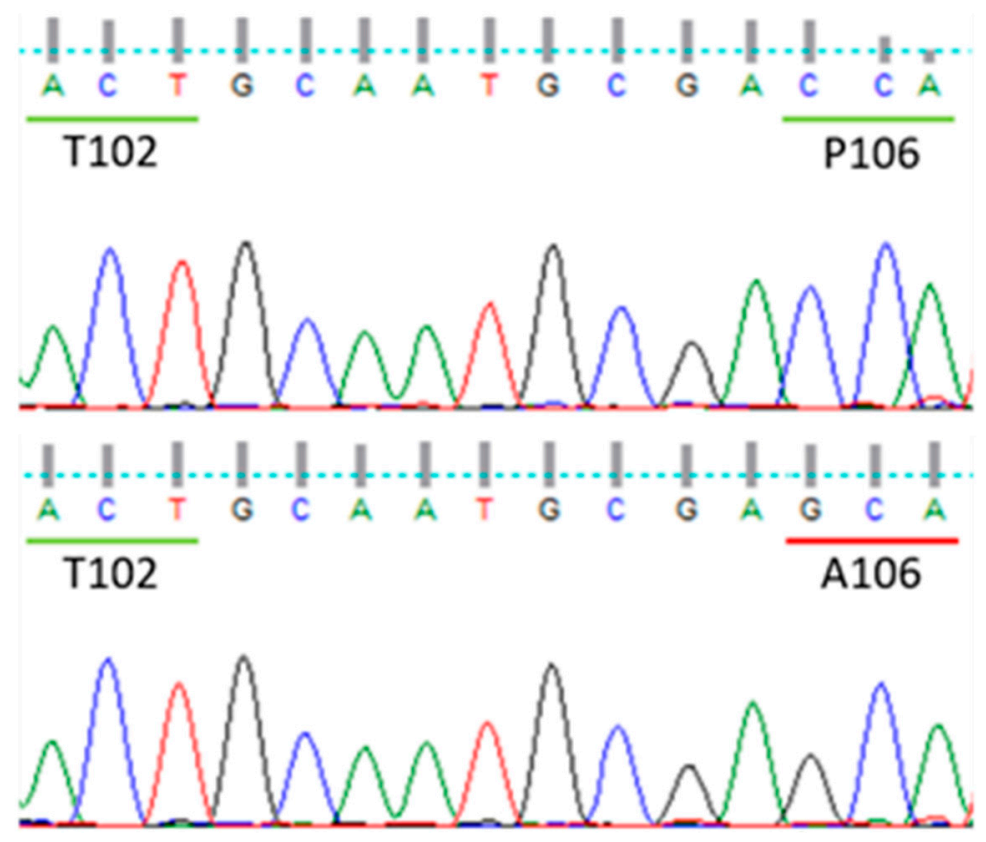

Figure 4. Screenshot of chromatograms obtained from a susceptible plant of 19-S biotype (upper graph) and a resistant plant of biotype 19-1 (bottom graph). Only codons from 102 to 106 are shown.

\section{Discussion}

Biotype 19-1 has an intermediate level of glyphosate resistance, with an RI of 7.3 and 5.8 for plant survival and fresh weight, respectively. $\mathrm{ED}_{50,90}, \mathrm{GR}_{50,90}$ and RI estimated for biotype 19-1 are in keeping with previous studies on GR populations of $E$. indica with target site resistance due to single 
amino acid substitution at position 106 in EPSPS gene [23,28-30]. Higher levels of resistance were instead described in E. indica populations with the double amino acid substitution at positions 102 and 106 (TIPS) [28,34] or having EPSPS amplification plus the substitution at position 106 [24,29].

All plants of biotype 19-1 were homozygous for the point mutation CCA to GCA at position 106 of the EPSPS gene, which caused an amino acid change from proline to alanine (P106A). E. indica is a self-pollinating species, thus homozygosity is expected some generations after the start of the selection process. Consistently, a previous work did not find heterozygous plants for mutations at this locus [41]. Heterozygosity was observed in the case of E. indica with the double point mutation called TIPS (T102I/P106S), but this might be due to the high fitness cost of that mutation [35]. Since all the sampled plants of biotype 19-1 had the same point mutation and consequently the same amino acid substitution (P106A), this is likely the main glyphosate resistance mechanism for this biotype. The amino acid substitution P106A detected in the EPSPS gene of 19-1 plants has been reported only once for E. indica and in a single GR biotype collected in tea plantations in China [29], but it has already been described for other grass species such as Lolium rigidum and Poa annua [42,43]. Considering both results of the dose-response experiment and molecular analysis, the biotype 19-1 can be confirmed as glyphosate-resistant, therefore, representing the first case of GR and more generally herbicide-resistant population of E. indica in Europe.

Although glyphosate doses above $2880 \mathrm{~g}_{\text {ae }} \mathrm{ha}^{-1}$ also controlled biotype 19-1, other control tools and tactics should be used. Control efficacy could be lower under field conditions, due to environmental factors or non-optimal application. The use of glyphosate as the only weed control tool could lead to an increased frequency of GR biotype in the local E. indica population or even to the evolution of further resistance mechanisms, such as the double 102-106 substitution or the EPSPS gene amplification, and consequently an increase in the resistance level. Integrating glyphosate with other herbicides with different SoA is recommendable for chemical control of E. indica in this area. Unfortunately, resistant biotypes to several herbicides and SoAs, such as the protoporphyrinogen oxidase (PPO) - inhibitor oxadiazon [44], ACCase-inhibitors [26,27] or the photosystem II inhibitor metribuzin [45], have already been reported in several countries. Specific strategies, such as rotation and/or a mixture of herbicides with different SoA, should be adopted to avoid the potential evolution of resistance to other herbicides. Organic acids with herbicidal effect, such as pelargonic acid, can be interesting management tools for this resistant weed. Their application provokes fast and nonselective desiccation of plant green tissue and the evolution of resistance against this effect is believed unlikely since multiple targets are affected by their action [46]. Mechanical and physical control methods could in theory play an important role for the sustainable management of this GR biotype. However, they are hardly adoptable in a plant nursery due to the presence of plant pots, irrigation pipes and plastic mulches.

Elucidating the process that led this GR biotype to establish itself is relevant for designing management strategies to limit the selection of glyphosate resistance across E. indica populations in other areas. It is suspected that biotype 19-1 evolved from a susceptible local population because of the high selection pressure exerted by the repeated use of glyphosate as the only weed control tool in the plant nursery. Otherwise, biotype 19-1 could have been introduced to that plant nursery from areas where GR populations of E. indica are common. Seeds of E. indica could be transported inside pots of ornamental plants or potting substrates that were regularly imported from abroad by the farm. However, the presence of an amino acid substitution (P106A) previously described only once in a E. indica population collected in China [29], instead of the more common P106S, might support the theory of in situ evolution instead of introduction of the GR biotype from other world areas.

To minimize the risk of GR E. indica biotype spreading, the overall management should take into consideration both processes. That is reducing the selection pressure exerted by glyphosate, by integrating alternative herbicides and control tools, to avoid in situ evolution and monitoring imported plants and substrates to promptly identify potential introduction of GR biotypes. Given that E. indica is a self-pollinating species, the spread of glyphosate resistance via pollen flow is 
negligible. Efforts should be directed to avoid dissemination of GR biotype, removing all plants that survived herbicide treatments and minimizing the risk of seed transport by machinery, plant materials, or substrates. Given that $E$. indica has a longer seed longevity in comparison with other grass weed species, with high seed viability reported even after three years of burial [47], these strategies should be repeated for several years in order to significantly reduce the soil seed bank of the 19-1 GR biotype at local level.

Author Contributions: Conceptualization, D.L., G.I. and G.Z.; Formal analysis, D.L. and A.M.; Investigation, D.L., G.I., A.M., S.P. and S.F.; Methodology, A.M., S.P. and S.F.; Resources, G.I.; Supervision, M.S. and G.Z.; Visualization, D.L. and A.M.; Writing—original draft, D.L. and A.M.; Writing—review and editing, G.I., S.P., S.F., M.S. and G.Z. All authors have read and agreed to the published version of the manuscript.

Funding: This research received no external funding.

Acknowledgments: The authors are grateful to Alison Garside for revising the English text.

Conflicts of Interest: The authors declare no conflict of interest.

\section{References}

1. Duke, S.O.; Powles, S.B. Glyphosate: A once-in-a-century herbicide. Pest Manag. Sci. 2008, 64, 319-325. [CrossRef] [PubMed]

2. Duke, S.O. The history and current status of glyphosate. Pest Manag. Sci. 2018, 74, 1027-1034. [CrossRef] [PubMed]

3. Powles, S.B.; Lorraine-Colwill, D.F.; Dellow, J.J.; Preston, C. Evolved resistance to glyphosate in rigid ryegrass (Lolium rigidum) in Australia. Weed Sci. 1998, 46, 604-607. [CrossRef]

4. Heap, I. The International Herbicide-Resistant Weed Database. Available online: www.weedscience.org (accessed on 30 October 2020).

5. Heap, I.; Duke, S.O. Overview of glyphosate-resistant weeds worldwide. Pest Manag. Sci. 2018, 74, 1040-1049. [CrossRef]

6. Amaro-Blanco, I.; Fernández-Moreno, P.T.; Osuna-Ruiz, M.D.; Bastida, F.; De Prado, R. Mechanisms of glyphosate resistance and response to alternative herbicide-based management in populations of the three Conyza species introduced in southern Spain. Pest Manag. Sci. 2018, 74, 1925-1937. [CrossRef]

7. Tahmasebi, B.K.; Alebrahim, M.T.; Roldán-Gómez, R.A.; Silveira, H.M.D.; Carvalho, L.B.D.; Alcántara-de la Cruz, R.; De Prado, R. Effectiveness of alternative herbicides on three Conyza species from Europe with and without glyphosate resistance. Crop Prot. 2018, 112, 350-355. [CrossRef]

8. Travlos, I.S.; Chachalis, D. Assessment of glyphosate-resistant horseweed (Conyza canadensis L. Cronq.) and fleabane (Conyza albida Willd. ex Spreng) populations from perennial crops in Greece. Int. J. Plant Prod. 2013, 7, 665-676.

9. Fernández-Moreno, P.T.; Travlos, I.; Brants, I.; De Prado, R. Different levels of glyphosate-resistant Lolium rigidum L. among major crops in southern Spain and France. Sci. Rep. 2017, 7, 13116. [CrossRef]

10. Collavo, A.; Sattin, M. Resistance to glyphosate in Lolium rigidum selected in Italian perennial crops: Bioevaluation, management and molecular bases of target-site resistance. Weed Res. 2012, 52, 16-24. [CrossRef]

11. Vázquez-García, J.G.; Palma-Bautista, C.; Rojano-Delgado, A.M.; De Prado, R.; Menendez, J. The first case of glyphosate resistance in johnsongrass (Sorghum halepense (L.) Pers.) in Europe. Plants 2020, 9, 313. [CrossRef]

12. Vázquez-García, J.G.; Castro, P.; Torra, J.; Alcántara-de la Cruz, R.; De Prado, R. Resistance evolution to EPSPS inhibiting herbicides in false barley (Hordeum murinum) harvested in Southern Spain. Agronomy 2020, 10, 992. [CrossRef]

13. USDA-ARS. Germplasm Resources Information Network (GRIN). Online Database. Beltsville, Maryland, USA: National Germplasm Resources Laboratory. Available online: https://npgsweb.ars-grin.gov/gringlobal/ taxon/taxonomydetail?id=14997 (accessed on 30 October 2020).

14. Holm, L.G.; Plucknett, D.L.; Pancho, J.V.; Herberger, J.P. The World's Worst Weeds: Distribution and Biology; University Press of Hawaii: Honolulu, HI, USA, 1977.

15. Pignatti, S. Flora d'Italia, 1st ed.; Edagricole: Bologna, Italy, 1982; Volume 3, p. 600. 
16. Zanin, G.; Cantele, A.; Della Pietà, S.; Lorenzoni, G.G.; Tei, F.; Vazzana, C. Le Erbe Infestanti Graminacee Nelle a Moderna Agricoltura: Dinamica, Problemi e Possibili Soluzioni; Atti Società Italiana per lo Studio della Lotta alle Malerbe (S.I.L.M): Verona, Italy, 14 November 1985; Tipografia Guerra: Perugia, Italy, 1985; pp. 13-248.

17. Motti, R.; Espodito, A.; Stinca, A. New additions s to the exotic vascular flora of Campania (Southern Italy). Ann. Bot. Italy 2018, 8, 75-85. [CrossRef]

18. Ampong-Nyarko, K.; de Datta, S.K.; Dingkuhn, M. Physiological response of rice and weeds to low light intensity at different growth stages. Weed Res. 1992, 32, 465-472. [CrossRef]

19. Lee, L.J.; Ngim, J. A first report of glyphosate-resistant goosegrass (Eleusine indica (L) Gaertn) in Malaysia. Pest Manag. Sci. 2000, 56, 336-339. [CrossRef]

20. Chen, J.-C.; Huang, H.-J.; Wei, S.-H.; Zhang, C.-X.; Huang, Z.-F. Characterization of glyphosate-resistant goosegrass (Eleusine indica) populations in China. J. Integr. Agric. 2015, 14, 919-925. [CrossRef]

21. Kaundun, S.S.; Zelaya, I.A.; Dale, R.P.; Lycett, A.J.; Carter, P.; Sharples, K.R.; McIndoe, E. Importance of the P106S target-site mutation in conferring resistance to glyphosate in a goosegrass (Eleusine indica) population from the Philippines. Weed Sci. 2008, 56, 637-646. [CrossRef]

22. Tampubolon, K.; Purba, E.; Basyuni, M.; Hanafiah, D.S. Glyphosate resistance of Eleusine indica populations from North Sumatra, Indonesia. Biodiversitas 2019, 20, 1910-1916. [CrossRef]

23. Takano, H.K.; Oliveira, R.S.; Constantin, J.; Braz, G.B.P.; Gheno, E.A. Goosegrass resistant to glyphosate in Brazil [Capim-pé-de-galinha resistente ao glyphosate no Brasil]. Planta Daninha 2017, 35, e017163071. [CrossRef]

24. Gherekhloo, J.; Fernández-Moreno, P.T.; Alcántara-De La Cruz, R.; Sánchez-González, E.; Cruz-Hipolito, H.E.; Domínguez-Valenzuela, J.A.; De Prado, R. Pro-106-Ser mutation and EPSPS overexpression acting together simultaneously in glyphosate-resistant goosegrass (Eleusine indica). Sci. Rep. 2017, 7, 6702. [CrossRef]

25. Mueller, T.C.; Barnett, K.A.; Brosnan, J.T.; Steckel, L.E. Glyphosate-resistant goosegrass (Eleusine indica) confirmed in Tennessee. Weed Sci. 2011, 59, 562-566. [CrossRef]

26. Jalaludin, A.; Yu, Q.; Powles, S.B. Multiple resistance across glufosinate, glyphosate, paraquat and ACCase-inhibiting herbicides in an Eleusine indica population. Weed Res. 2015, 55, 82-89. [CrossRef]

27. Deng, W.; Yang, Q.; Chen, Y.; Yang, M.; Xia, Z.; Zhu, J.; Chen, Y.; Cai, J.; Yuan, S. Cyhalofop-butyl and glyphosate multiple-herbicide resistance evolved in an Eleusine indica population collected in Chinese direct-seeding rice. J. Agric. Food Chem. 2020, 68, 2623-2630. [CrossRef]

28. Chen, J.; Jiang, C.; Huang, H.; Wei, S.; Huang, Z.; Wang, H.; Zhao, D.; Zhang, C. Characterization of Eleusine indica with gene mutation or amplification in EPSPS to glyphosate. Pestic. Biochem. Physiol. 2017, 143, 201-206. [CrossRef]

29. Chen, J.; Huang, H.; Wei, S.; Cui, H.; Li, X.; Zhang, C. Glyphosate resistance in Eleusine indica: EPSPS overexpression and P106A mutation evolved in the same individuals. Pestic. Biochem. Physiol. 2020, 164, 203-208. [CrossRef] [PubMed]

30. Huffman, J.L.; Riggins, C.W.; Steckel, L.E.; Tranel, P.J. The EPSPS Pro106Ser substitution solely accounts for glyphosate resistance in a goosegrass (Eleusine indica) population from Tennessee, United States. J. Integr. Agric. 2016, 15, 1304-1312. [CrossRef]

31. Chen, J.; Huang, H.; Zhang, C.; Wei, S.; Huang, Z.; Chen, J.; Wang, X. Mutations and amplification of EPSPS gene confer resistance to glyphosate in goosegrass (Eleusine indica). Planta 2015, 242, 859-868. [CrossRef]

32. Ng, C.H.; Wickneswari, R.; Salmijah, S.; Teng, Y.T.; Ismail, B.S. Gene polymorphisms in glyphosate-resistant and -susceptible biotypes of Eleusine indica from Malaysia. Weed Res. 2003, 43, 108-115. [CrossRef]

33. Takano, H.K.; Mendes, R.R.; Scoz, L.B.; Lopez Ovejero, R.F.; Constantin, J.; Gaines, T.A.; Westra, P.; Dayan, F.E.; Oliveira, R.S. Proline-106 EPSPS mutation imparting glyphosate resistance in goosegrass (Eleusine indica) Emerges in South America. Weed Sci. 2019, 67, 48-56. [CrossRef]

34. Yu, Q.; Jalaludin, A.; Han, H.; Chen, M.; Douglas Sammons, R.; Powles, S.B. Evolution of a double amino acid substitution in the 5-enolpyruvylshikimate-3-phosphate synthase in Eleusine indica conferring high-level glyphosate resistance. Plant Physiol. 2015, 167, 1440-1447. [CrossRef] [PubMed]

35. Han, H.; Vila-Aiub, M.M.; Jalaludin, A.; Yu, Q.; Powles, S.B. A double EPSPS gene mutation endowing glyphosate resistance shows a remarkably high resistance cost. Plant Cell. Environ. 2017, 40, 3031-3042. [CrossRef] 
36. Zhang, C.; Feng, L.; He, T.T.; Yang, C.H.; Chen, G.Q.; Tian, X.S. Investigating the mechanisms of glyphosate resistance in goosegrass (Eleusine indica) population from South China. J. Integr. Agric. 2015, 14, 909-918. [CrossRef]

37. Hess, M.; Barralis, G.; Bleiholder, H.; Buhr, L.; Eggers, T.; Hack, H.; Stauss, R. Use of the extended BBCH scale-General for the descriptions of the growth stages of mono- and dicotyledonous weed species. Weed Res. 1997, 37, 433-441. [CrossRef]

38. Onofri, A. Bioassay97: A new Excel VBA macro to perform statistical analyses on herbicide dose-response data. Riv. Ital. Agrometeorol. 2005, 3, 40-45.

39. Aras, S.; Duran, A.; Yenilmez, G. Isolation of DNA for RAPD analysis from dry leaf material of some Hesperis L. specimens. Plant Mol. Biol. Rep. 2003, 21, 461-462. [CrossRef]

40. Milani, A.; Panozzo, S.; Farinati, S.; Loddo, D. Molecular data for: First report of glyphosate-resistant biotype of Eleusine indica in Europe. Mendeley Data 2020, V1. [CrossRef]

41. Molin, W.; Wright, A.; Nandula, V. Glyphosate-resistant goosegrass from Mississippi. Agronomy 2013, 3, 474-487. [CrossRef]

42. Yu, Q.; Cairns, A.; Powles, S. Glyphosate, paraquat and ACCase multiple herbicide resistance evolved in a Lolium rigidum biotype. Planta 2007, 225, 499-513. [CrossRef] [PubMed]

43. Cross, R.B.; McCarty, L.B.; Tharayil, N.; McElroy, J.S.; Chen, S.; McCullough, P.E.; Powell, B.A.; Bridges, W.C. A Pro 106 to Ala Substitution is associated with resistance to glyphosate in annual bluegrass (Poa annua). Weed Sci. 2015, 63, 613-622. [CrossRef]

44. Bi, B.; Wang, Q.; Coleman, J.J.; Porri, A.; Peppers, J.M.; Patel, J.D.; Betz, M.; Lerchl, J.; McElroy, J.S. A novel mutation A212T in chloroplast Protoporphyrinogen oxidase (PPO1) confers resistance to PPO inhibitor Oxadiazon in Eleusine indica. Pest Manag. Sci. 2020, 76, 1786-1794. [CrossRef]

45. Brosnan, J.T.; Nishimoto, R.K.; DeFrank, J. Metribuzin-resistant goosegrass (Eleusine indica) in bermudagrass turf. Weed Technol. 2008, 22, 675-678. [CrossRef]

46. Perotti, V.E.; Larran, A.S.; Palmieri, V.E.; Martinatto, A.K.; Permingeat, H.R. Herbicide resistant weeds: A call to integrate conventional agricultural practices, molecular biology knowledge and new technologies. Plant Sci. 2020, 290, 110255. [CrossRef] [PubMed]

47. Masin, R.; Zuin, M.C.; Otto, S.; Zanin, G. Seed longevity and dormancy of four summer annual grass weeds in turf. Weed Res. 2006, 46, 362-370. [CrossRef]

Publisher's Note: MDPI stays neutral with regard to jurisdictional claims in published maps and institutional affiliations.

(C) 2020 by the authors. Licensee MDPI, Basel, Switzerland. This article is an open access article distributed under the terms and conditions of the Creative Commons Attribution (CC BY) license (http://creativecommons.org/licenses/by/4.0/). 